\title{
Ruminal Degradability and Lysine Bioavailability of Soybean Meals and Effects on Performance of Dairy Cows ${ }^{1}$
}

\author{
M. S. Awawdeh, E. C. Titgemeyer, ${ }^{2}$ J. S. Drouillard, R. S. Beyer, and J. E. Shirley \\ Department of Animal Sciences and Industry, Kansas State University, Manhattan 66506-1600
}

\section{ABSTRACT}

Evaluations of 4 soybean meal (SBM) products were conducted in 3 experiments. The 4 products were 1) solvent SBM (SSBM), 2) SSBM treated with $0.05 \%$ baker's yeast and toasted at $\left.100^{\circ} \mathrm{C}(\mathrm{YSBM}), 3\right)$ expeller SBM (ESBM), and 4) lignosulfonate-treated SBM (LSBM). Multiparous Holstein cows ( $\mathrm{n}=32 ; 152 \pm 63$ $\mathrm{d}$ in milk; body weight $=708 \pm 77 \mathrm{~kg}$; producing $41 \pm 7$ $\mathrm{kg} / \mathrm{d}$ of milk at the beginning of the study) were used in a $4 \times 4$ Latin square design with 28 -d periods to investigate cow responsiveness to supplemental ruminally undegradable protein (RUP) from the SBM products. Dietary treatments were formulated by substituting all of the SSBM and part of the ground corn with YSBM, ESBM, or LSBM to yield isonitrogenous diets. Diets were formulated to provide adequate ruminally degradable protein, but deficient RUP and metabolizable protein supplies. No differences among dietary treatments were observed for dry matter intake, body weight gain, milk and component yields, or efficiency of milk production. The lack of response to changes in SBM source was likely due to an adequate RUP and metabolizable protein supply by all the diets. In situ ruminal degradations of YSBM and LSBM were slower than those of SSBM or ESBM; thus, RUP contents of YSBM and LSBM were greater than those of SSBM or ESBM. The RUP of all SBM products had similar small intestinal digestibility. Available Lys contents, estimated chemically or by using a chick growth assay, were less for YSBM and LSBM than for SSBM or ESBM, suggesting deleterious effects of processing on Lys availability in YSBM and LSBM.

Key words: dairy cow, soybean meal, lysine bioavailability

\footnotetext{
Received March 19, 2007.

Accepted June 18, 2007.

${ }^{1}$ Contribution number 06-330-J from the Kansas Agricultural Experiment Station, Manhattan, Kansas. Research was funded by Carr's Milling Industries PLC and AFGRI Operations Limited.

${ }^{2}$ Corresponding author: etitgeme@ksu.edu
}

\section{INTRODUCTION}

Metabolizable protein requirements of dairy cows are met by microbial protein and by dietary protein that escapes the rumen. In early lactation, microbial protein is not able to support milk production in high-producing dairy cows. Thus, supplementing RUP is warranted. Increasing the RUP supply from plant and animal products improves the performance (yield of milk and protein) of dairy cows (NRC, 2001). Whole soybeans and soybean meal (SBM) are the most commonly used supplemental plant proteins in the United States (Lin and Kung, 1999). Soybean products are characterized by high palatability and well-balanced and available essential AA (EAA) contents. Among the 11 protein sources evaluated, the EAA index of soybean bypass protein is the second best after microbial protein (Chandler, 1989), but extensive ruminal degradability ( $74 \%$ for whole soybeans and $71 \%$ for SBM; NRC, 2001) limits the utilization of these soybean products by ruminants as sources of RUP. Various methods have been used to treat soybean products to alter their ruminal degradability and consequently increase their escape protein content, but "overprotection" can impair the protein quality of SBM by altering the nutritional availability of AA, particularly Lys (Faldet et al., 1992). The objectives of our study were to compare the nutritive value of 4 SBM products in terms of the performance of dairy cows (experiment 1), ruminal degradation kinetics and intestinal digestibility (experiment 2), and Lys bioavailability (experiment 3).

\section{MATERIALS AND METHODS}

The use of animals in all experiments was approved by the Kansas State University Institutional Animal Care and Use Committee. In 3 experiments, a comprehensive evaluation of $4 \mathrm{SBM}$ products was conducted. The 4 products were 1) solvent SBM (SSBM), 2) SSBM treated with $0.05 \%$ baker's yeast (Saccharomyces cerevisiae) and steeped for $10 \mathrm{~min}$ at $30^{\circ} \mathrm{C}$ before toasting at $100^{\circ} \mathrm{C}$ (YSBM), 3) expeller SBM (ESBM), and 4) lignosulfonate-treated SBM (LSBM). 


\section{Experiment 1: Production Study}

Thirty-two multiparous Holstein cows averaging 152 \pm 63 DIM, $708 \pm 77 \mathrm{~kg}$ of BW, and $41 \pm 7 \mathrm{~kg} / \mathrm{d}$ of milk at the beginning of the study were blocked by DIM, BW, milk production, and lactation number, and were assigned to 1 of 4 free-stall pens in a $4 \times 4$ Latin square balanced for carryover effects. The lactation number of cows ranged between 2 and 7, averaging 3.1. The experimental units were pens of 8 cows. The 4 dietary treatments (Table 1) were formulated to be isonitrogenous by substituting all SSBM and part of the ground corn with YSBM, ESBM, or LSBM. The control (SSBM) diet was formulated to supply adequate amounts of RDP, but deficient amounts of RUP, and consequently to be deficient in MP supply (NRC, 2001) for the described cows. In addition, diets were formulated to be more limited by Lys supply than by Met supply by adding Met from MetaSmart (Adisseo, Alpharetta, GA) to all diets; this was to investigate the responsiveness of cows to RUP and Lys supplies from the SBM products. Cows were injected throughout the study with recombinant bST (Posilac, Monsanto, St. Louis, MO) at 14-d intervals. Each period was $28 \mathrm{~d}$ with a 14-d adaptation and $14 \mathrm{~d}$ for data collection. Only data from the last 14 $\mathrm{d}$ for each period were used for statistical analyses.

Diets were fed as TMR and offered twice daily at 0500 and $1130 \mathrm{~h}$. The amount of TMR offered and refused was recorded daily for each pen and was adjusted to ensure orts of about $10 \%$ of intake and ad libitum consumption. Samples of orts were collected daily, and $\mathrm{DM}\left(105^{\circ} \mathrm{C}\right.$ in a forced-air oven for $\left.24 \mathrm{~h}\right)$ was measured to determine daily DMI. Samples of corn silage were collected weekly to measure DM, and its inclusion in diets was adjusted accordingly. During the collection period, samples of dietary ingredients (alfalfa hay, corn silage, cottonseed, and corn-based grain mix) were collected weekly, composited by period, and saved $\left(-20^{\circ} \mathrm{C}\right)$ for later analysis of $\mathrm{DM}\left(105^{\circ} \mathrm{C}\right.$ in a forced-air oven for $24 \mathrm{~h}$ ), NDF (with amylase and sulfite), ADF (Ankom Technology Corp., Fairport, NY), and CP (Leco FP 2000 Nitrogen Analyzer, Leco Corporation, St. Joseph, MI). Diet concentrations of $\mathrm{CP}, \mathrm{NDF}$, and $\mathrm{ADF}$ were calculated based on the analyzed composition of weekly samples of ingredients. Values for NDF and ADF were not corrected for ash content. Dietary concentrations of RDP, RUP, $\mathrm{NE}_{\mathrm{L}}$, duodenal Met and Lys supplies, Ca, $\mathrm{P}$, and S were estimated according to NRC (2001) guidelines.

Each SBM product was analyzed for DM $\left(105^{\circ} \mathrm{C}\right.$ in a forced-air oven for $24 \mathrm{~h}$ ), NDF, ADF, ether extract (AOAC, 1984), CP, and AA profile by using HPLC with postcolumn derivitization with $o$-phthalaldehyde after acid hydrolysis $\left(6 \mathrm{~N} \mathrm{HCl}\right.$ at $105^{\circ} \mathrm{C}$ for $24 \mathrm{~h}$; Table 2$)$.
Table 1. Diet composition (experiment 1)

\begin{tabular}{|c|c|c|c|c|}
\hline \multirow[b]{2}{*}{ Item } & \multicolumn{4}{|c|}{ Treatment $^{1}$} \\
\hline & SSBM & YSBM & ESBM & LSBM \\
\hline \multicolumn{5}{|l|}{ Ingredient } \\
\hline Alfalfa & 30.7 & 30.7 & 30.7 & 30.6 \\
\hline Corn, ground & 26.2 & 26.2 & 24.8 & 25.5 \\
\hline Corn silage & 16.5 & 16.5 & 16.5 & 16.4 \\
\hline Whole cottonseed & 8.9 & 8.9 & 8.9 & 8.8 \\
\hline SBM (respective product) & 6.9 & 6.8 & 8.3 & 7.6 \\
\hline Soybean hulls & 6.8 & 6.8 & 6.8 & 6.9 \\
\hline Molasses & 1.2 & 1.2 & 1.2 & 1.2 \\
\hline Limestone & 1.0 & 1.0 & 1.0 & 1.0 \\
\hline Sodium bicarbonate & 0.81 & 0.81 & 0.81 & 0.81 \\
\hline Calcium phosphate & 0.34 & 0.34 & 0.34 & 0.34 \\
\hline Trace mineral salt ${ }^{2}$ & 0.29 & 0.29 & 0.29 & 0.29 \\
\hline Magnesium oxide & 0.20 & 0.20 & 0.20 & 0.20 \\
\hline MetaSmart $^{3}$ & 0.14 & 0.14 & 0.14 & 0.14 \\
\hline Vitamin ADE premix ${ }^{4}$ & 0.14 & 0.14 & 0.14 & 0.14 \\
\hline Trace mineral premix ${ }^{5}$ & 0.05 & 0.05 & 0.05 & 0.05 \\
\hline Sodium selenite premix ${ }^{6}$ & 0.01 & 0.01 & 0.01 & 0.01 \\
\hline \multicolumn{5}{|l|}{ Nutrient } \\
\hline $\mathrm{CP}$ & 16.8 & 16.8 & 16.7 & 17.3 \\
\hline $\mathrm{RDP}^{7}$ & 11.3 & 10.4 & 11.1 & 10.8 \\
\hline $\mathrm{RUP}^{7}$ & 5.5 & 6.4 & 5.6 & 6.5 \\
\hline $\mathrm{NDF}$ & 32.0 & 33.1 & 32.5 & 31.8 \\
\hline $\mathrm{ADF}$ & 19.8 & 19.7 & 20.0 & 19.1 \\
\hline $\mathrm{Ca}^{7}$ & 1.08 & 1.08 & 1.09 & 1.09 \\
\hline $\mathrm{P}^{7}$ & 0.40 & 0.40 & 0.40 & 0.40 \\
\hline \multirow[t]{2}{*}{$\mathrm{S}^{7}$} & 0.22 & 0.22 & 0.22 & 0.22 \\
\hline & & \multicolumn{2}{|c|}{$\mathrm{Mcal} / \mathrm{kg}$ of $\mathrm{DM}$} & 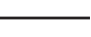 \\
\hline \multirow[t]{2}{*}{$\mathrm{NE}_{\mathrm{L}}{ }^{7}$} & 1.57 & 1.57 & 1.57 & 1.56 \\
\hline & & $-\%$ & $\mathrm{MP}$ & \\
\hline $\mathrm{Met}^{7}$ & 2.14 & 2.10 & 2.14 & 2.11 \\
\hline Lys $^{7}$ & 6.51 & 6.39 & 6.51 & 6.41 \\
\hline
\end{tabular}

${ }^{1} \mathrm{SSBM}=$ solvent soybean meal $(\mathrm{SBM}) ; \mathrm{YSBM}=\mathrm{SSBM}$ treated with $0.05 \%$ baker's yeast (Saccharomyces cerevisiae) and steeped for 10 min at $30^{\circ} \mathrm{C}$ before toasting at $100^{\circ} \mathrm{C} ; \mathrm{ESBM}=$ expeller $\mathrm{SBM} ; \mathrm{LSBM}=$ lignosulfonate-treated SBM.

${ }^{2}$ Composition: $94 \% \mathrm{NaCl}, 0.35 \% \mathrm{Zn}, 0.20 \% \mathrm{Fe}, 0.20 \% \mathrm{Mg}, 0.03 \%$ $\mathrm{Cu}, 0.007 \% \mathrm{I}$, and $0.005 \% \mathrm{Co}$.

${ }^{3}$ Composition: $57 \%$ of isopropyl ester of 2-hydroxy-4-methylthiobutanoic acid monomer esters (MetaSmart, Adisseo, Alpharetta, GA).

${ }^{4}$ Provided 5,280 IU of vitamin A, 2,640 IU of vitamin D, and 33 IU of vitamin E per kg of dietary DM.

${ }^{5}$ Provided not less than $13 \mathrm{mg}$ of $\mathrm{Zn}$ from zinc Met, $7 \mathrm{mg}$ of $\mathrm{Mn}$ from manganese Met, $4.5 \mathrm{mg}$ of $\mathrm{Cu}$ from copper Lys, and $0.9 \mathrm{mg}$ of Co from cobalt glucoheptonate per kg of dietary DM (Zinpro 4-plex, Zinpro, Eden Prairie, MN).

${ }^{6}$ Provided $0.06 \mathrm{mg}$ of Se per kg of dietary DM.

${ }^{7}$ Calculated according to the NRC (2001). MetaSmart was assumed to supply $22.2 \%$ of weight as metabolizable Met.

Before NDF and ADF analyses, SBM samples were extracted with acetone for $12 \mathrm{~h}$. Residuals after NDF and ADF extraction were analyzed for N (Kjeldahl; AOAC, 1984) to determine neutral detergent insoluble nitrogen (NDIN) and ADIN.

Cows were milked twice daily, at 0730 and $1930 \mathrm{~h}$, and individual milk weights were recorded. Composite milk samples (a.m., p.m.) from individual cows were collected weekly and analyzed for protein, fat, lactose, 
Table 2. Nutrient composition of soybean (SBM) products

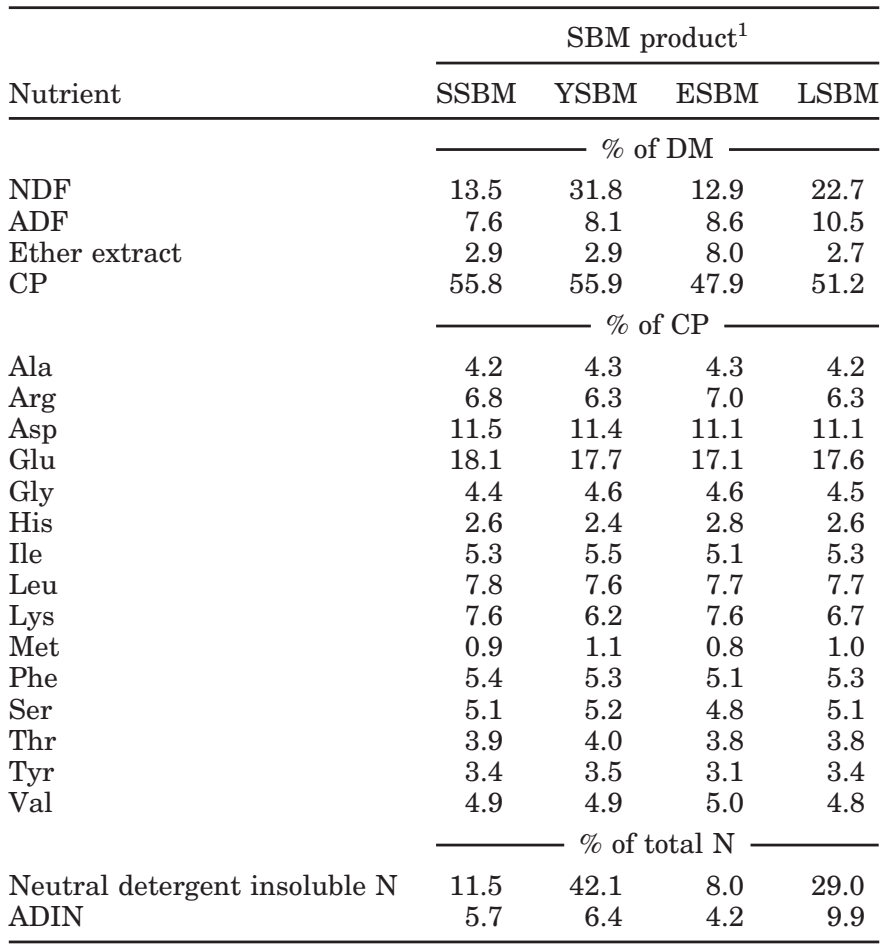

${ }^{1} \mathrm{SSBM}=$ solvent SBM; YSBM = SSBM treated with $0.05 \%$ baker's yeast (Saccharomyces cerevisiae) and steeped for $10 \mathrm{~min}$ at $30^{\circ} \mathrm{C}$ before toasting at $100^{\circ} \mathrm{C} ; \mathrm{ESBM}=$ expeller $\mathrm{SBM} ; \mathrm{LSBM}=$ lignosulfonate-treated SBM.

SNF, MUN, and SCC by the Heart of America DHI Laboratory (Manhattan, KS). Milk protein, fat, and lactose contents were analyzed by near-infrared spectroscopy (Bentley 2000 Infrared Milk Analyzer, Bentley Instruments, Chaska, MN). A modified Berthelot reaction (ChemSpec 150 Analyzer, Bentley Instruments) was used to determine MUN. Flow cytometry (Somacount 500, Bentley Instruments) was used to determine SCC. For cows that developed mastitis (3 cases) or lameness ( 3 cases), milk production from $1 \mathrm{~d}$ before and until the resolution of the case was not used to calculate weekly averages for that cow.

Immediately after the morning milking, cows were weighed and scored for body condition (scale of 1 to 5) at the beginning of the study and at the end of each period. At the same times, blood samples were collected from the coccygeal vein into vacuum tubes (Becton Dickinson, Franklin Lakes, NJ) containing sodium heparin, immediately chilled on ice, centrifuged for $20 \mathrm{~min}$ at $1,000 \times g$ to obtain plasma, and stored $\left(-20^{\circ} \mathrm{C}\right)$ for later analysis of glucose (Gochman and Schmitz, 1972) and urea (Marsh et al., 1965) of individual samples. Plasma samples were composited by pen for each period and stored $\left(-20^{\circ} \mathrm{C}\right)$ for later analysis of $\mathrm{AA}$, after depro- teinization with sulfosalicylic acid, by using HPLC with postcolumn derivitization with $o$-phthalaldehyde.

Statistical Analyses. Data from 1 cow for the last 2 periods were missing because she was removed from the study for reasons not related to treatment. Six weekly milk-production averages for individual cows were not used for reasons unrelated to treatments (mastitis, lameness, and the cow that was removed from the study), leaving 250 weekly averages that were statistically analyzed. To account for differences in the production levels of cows with missing observations, weekly pen means for milk and component yields, SCC, and MUN were generated by using PROC MIXED of SAS (SAS System for Windows, Release 8.1, SAS Inst. Inc., Cary, NC) with a model including terms for pen $\times$ period $\times$ treatment $\times$ week and cow (pen). Daily DMI for each pen was adjusted for the sick cows (mastitis or lameness) in that pen according to level of milk production [adjusted DMI per cow $=$ actual pen DMI $\times($ milk production for healthy cows/total pen milk production)/number of healthy cows]. Data were analyzed statistically by using PROC MIXED of SAS.

For data collected daily (milk production and DMI) and weekly (milk composition), weekly averages were analyzed as a split plot, with Latin square as the main plot and week as the subplot. The model contained the effects of pen, period, treatment, week, and week $\times$ treatment. The pen $\times$ period $\times$ treatment interaction was included as a random variable and served as the main-plot error term. Data collected once per period (BW and BCS changes and plasma metabolites) were analyzed by using PROC MIXED of SAS according to a Latin square design. The model contained the effect of pen, period, and treatment. In experiment 1, as well as for all other experiments, treatment means were computed by using the LSMEANS option, and $F$-test protected pairwise $t$-tests among means were used for treatment separation.

\section{Experiment 2: In Situ Protein Degradability and Intestinal Digestibility of Ruminally Undegraded Nitrogen}

Two ruminally cannulated Jersey steers (average $\mathrm{BW}=518 \mathrm{~kg}$ ) were fed a typical dairy diet containing (DM basis) $15 \%$ alfalfa hay, $21 \%$ wet corn gluten feed, $22 \%$ corn silage, $6 \%$ ESBM, and $36 \%$ corn-based concentrate for ad libitum consumption. Daily DMI of steers averaged $9.0 \mathrm{~kg}$. To estimate in situ protein degradability, 1.5 to $2.0 \mathrm{~g}$ of ground (2-mm screen, Wiley mill, Arthur H. Thomas Co., Philadelphia, PA) samples of the $4 \mathrm{SBM}$ products were weighed in duplicate for each incubation time $(0,2,4,8,16,24$, and $48 \mathrm{~h})$ into polyester bags $(5 \times 10 \mathrm{~cm}, 53 \pm 10 \mu \mathrm{m}$ pore size, Ankom 
Technology Corp.). The sample weight to surface area ratio was approximately $17.5 \mathrm{mg} / \mathrm{cm}^{2}$, which is within the appropriate range (Nocek, 1988). Bags were heatsealed, presoaked in cold tap water, placed into a weighted mesh bag $(36 \times 42 \mathrm{~cm})$, and placed into the ventral sac of the rumen at different time points; all bags were then simultaneously removed from the rumen. Upon removal, bags (including $0 \mathrm{~h}$ ) were washed with cold water in a commercial top-loading washing machine (Kenmore Ultra Fabric Care, Sears, Roebuck and Co., Chicago, IL) with 1-min agitation at the delicate setting and 2-min spin per rinse as described by Coblentz et al. (1997), for 5 cycles, as recommended by Vanzant et al. (1998). After rinsing, bags were dried $\left(55^{\circ} \mathrm{C}\right.$ in a forced-air oven for $\left.24 \mathrm{~h}\right)$, air-equilibrated, and weighed to determine residual DM. Bags plus residuals were analyzed for Kjeldahl $\mathrm{N}$ to determine residual $\mathrm{N}$.

Protein fractions (A, B, and C) and the degradation rate of fraction $B\left(\mathbf{k}_{\mathbf{B}}\right)$ were estimated for each steer by using PROC NONLIN of SAS with the following model:

$$
\text { residual } \mathrm{N}=\left[\mathrm{B} \times \exp \left(-\mathrm{k}_{\mathrm{B}} \times \mathrm{t}\right)\right]+\mathrm{C},
$$

where B is the slowly degraded protein fraction, $\mathrm{C}$ is the completely undegradable protein fraction, $\mathrm{t}$ is incubation time, and $\mathrm{k}_{\mathrm{B}}$ is the degradation rate of fraction B. Fraction A was calculated by difference: A $=1-(B$ $+\mathrm{C})$.

Digestibility of ruminally undegraded nitrogen (RUN) was determined according to the 3-step procedure described by Calsamiglia and Stern (1995) using the in situ residues after $16 \mathrm{~h}$ of ruminal incubation. Ten bags for each SBM product were incubated to obtain enough residue to measure pepsin-pancreatin digestibility. After 16-h incubations, bags were removed and washed with cold water in a washing machine as described above. Intestinal digestibility of RUN was calculated as $\mathrm{N}$ in the supernatant as a percentage of added N (16-h bag residuals). Digestible $\mathrm{N}$ in the original SBM (before ruminal incubation) was calculated as RUN multiplied by intestinal digestibility of RUN.

Statistical Analyses. Data for residual N at each time point were analyzed statistically by using PROC MIXED of SAS (SAS System for Windows, Release 8.1, SAS Inst. Inc.) as a randomized-block design. The model contained the effect of steer, time, treatment, and treatment $\times$ time. Pool sizes (A, B, and $\mathrm{C})$ and $\mathrm{k}_{\mathrm{B}}$ for each SBM were analyzed statistically by using the PROC MIXED of SAS as a randomized-block design with a model containing the effect of treatment and steer. Data for intestinal digestibility of RUN were analyzed statistically by using PROC MIXED of SAS. The model contained the effects of steer and treatment.

\section{Experiment 3: Lys Bioavailability}

Extensive heating of SBM may impair Lys availability and consequently result in deleterious effects on overall protein quality. Available Lys contents of SBM products were investigated by using a chick growth assay and by chemical availability.

Broiler chicks ( $\mathrm{n}=480,1 \mathrm{~d}$ old) were used in a randomized complete-block design to compare the relative bioavailability of Lys in YSBM, ESBM, and LSBM with that of SSBM. Blocks were 4 temperature-regulated starter batteries (Petersime Incubator Co., Gettysburg, $\mathrm{OH})$ with 12 pens in each battery (total of 48 pens). Pens in each battery were randomly assigned to 1 of the 12 treatments (Table 3). Upon arrival from a commercial source, 10 birds were randomly selected, groupweighed, and placed into each of the 48 pens. Birds had free access to feed and water. At the conclusion of the study (9 d), each pen of birds was weighed to calculate $\mathrm{ADG}$, and unconsumed feed was weighed to allow calculation of DMI.

Twelve treatments were tested (Table 3), with the first 4 treatments containing SSBM at $20,23,26$, or $29 \%$ of DM to obtain a standard curve for the reference SSBM. A treatment containing $26 \%$ SSBM plus $0.15 \%$ L-Lys $\cdot \mathrm{HCl}$ was used to verify that Lys was the most limiting AA. The remaining 7 treatments were obtained by replacing SSBM in the $26 \%$ treatment with YSBM, ESBM, or LSBM or with residuals after 12-h ruminal incubation of the 4 SBM sources. These final 7 treatments were formulated to be isonitrogenous with the $26 \%$ SSBM by varying the amount of cornstarch added to diets.

Dry matter $\left(105^{\circ} \mathrm{C}\right.$ in a forced-air oven for $\left.24 \mathrm{~h}\right)$ of dietary ingredients (SBM, ground corn, and cornstarch) was measured. The SBM and ruminal residuals of each SBM were analyzed for CP (Leco FP 2000 Nitrogen Analyzer) and AA profile (HPLC). Ruminal residuals were obtained by using 4 ruminally cannulated Jersey steers (average $\mathrm{BW}=535 \mathrm{~kg}$ ) consuming a typical dairy diet, described in experiment 2 , for ad libitum consumption. Average DMI of steers was $9.2 \mathrm{~kg} / \mathrm{d}$. Approximately $200 \mathrm{~g}$ of SSBM, YSBM, ESBM, and LSBM was weighed into polyester bags $(45 \times 30 \mathrm{~cm}, 53 \pm 10 \mu \mathrm{m}$ pore size, Ankom Technology Corp.), with a ratio of sample weight to surface area of approximately $74 \mathrm{mg} /$ $\mathrm{cm}^{2}$. Bags were heat-sealed, individually placed into a weighted mesh bag $(36 \times 42 \mathrm{~cm})$, and placed in the ventral sac of the rumen in each steer (1 bag of each SBM product, total of 4 bags per steer for each incubation). After 12-h incubations, bags were removed and washed in cold water with a washing machine as described for experiment 2. After rinsing, bag residues were freeze-dried and weighed to determine residual 
Table 3. Diets fed to chick to evaluate Lys availability in original soybean meal (SBM) products and 12-h in situ residues of SBM products (experiment 3)

\begin{tabular}{|c|c|c|c|c|c|c|c|c|c|c|c|c|}
\hline Ingredient & \multicolumn{4}{|c|}{$\operatorname{SSBM}^{1}$} & $\begin{array}{l}26 \% \mathrm{SSBM}^{1}+ \\
0.15 \% \mathrm{Lys}^{2} \mathrm{HCl}\end{array}$ & \multicolumn{3}{|c|}{ Original SBM product ${ }^{1}$} & \multicolumn{4}{|c|}{$12-\mathrm{h}$ in situ residue ${ }^{1}$} \\
\hline & & & & & & $-\% \mathrm{c}$ & DM & & & & & \\
\hline SSBM & 20.2 & 23.3 & 26.3 & 29.3 & 26.3 & - & - & - & - & - & - & - \\
\hline YSBM & - & - & - & - & - & 27.8 & - & - & - & - & - & - \\
\hline ESBM & - & - & - & - & - & - & 30.9 & - & - & - & - & - \\
\hline Residue of ESBM & - & - & - & - & - & - & - & - & - & - & 22.4 & \\
\hline Residue of LSBM & - & - & - & - & - & - & - & - & - & - & - & 20.3 \\
\hline $\mathrm{Lys} \cdot \mathrm{HCl}^{2}$ & - & - & - & - & 0.15 & - & - & - & - & - & - & - \\
\hline Cornstarch & 10.9 & 7.9 & 5.0 & 2.0 & 4.8 & 3.7 & 0.2 & 1.4 & 12.9 & 12.4 & 10.1 & 11.9 \\
\hline Soybean oil & 4.5 & 4.5 & 4.5 & 4.5 & 4.5 & 4.5 & 4.5 & 4.5 & 4.4 & 4.4 & 4.4 & 4.4 \\
\hline L-Met & 0.3 & 0.3 & 0.3 & 0.3 & 0.3 & 0.3 & 0.3 & 0.3 & 0.3 & 0.3 & 0.3 & 0.3 \\
\hline
\end{tabular}

${ }^{1}$ The solvent SBM (SSBM) in the diet containing 26\% SSBM was replaced with SSBM treated with $0.05 \%$ baker's yeast (Saccharomyces cerevisiae) and steeped for $10 \mathrm{~min}$ at $30^{\circ} \mathrm{C}$ before toasting at $100^{\circ} \mathrm{C}$ (YSBM), expeller SBM (ESBM), or lignosulfonate-treated SBM (LSBM) or residuals after 12-h ruminal incubations of SSBM, YSBM, ESBM, or LSBM to yield isonitrogenous diets.

${ }^{2}$ Feed grade containing $78.8 \%$ Lys; provided $0.12 \%$ Lys to the diet.

${ }^{3}$ Provided $120 \mathrm{mg}$ of $\mathrm{Mn}, 120 \mathrm{mg}$ of $\mathrm{Zn}, 60 \mathrm{mg}$ of Fe, $13.5 \mathrm{mg}$ of Cu, $1.8 \mathrm{mg}$ of I, $0.18 \mathrm{mg}$ of Se, 9,240 IU of vitamin A, 3,300 IU of vitamin $\mathrm{D}$, and $20 \mathrm{IU}$ of vitamin E per kg of dietary DM.

DM, which averaged $48,62,50$, and $60 \%$ for SSBM, YSBM, ESBM, and LSBM, respectively.

In a preliminary study with large $(45 \times 30 \mathrm{~cm})$ polyester bags, we measured the 12 -h ruminal degradation by using polyester bags containing SSBM with sample weight to surface area ratios ranging from 20 to 221 $\mathrm{mg} / \mathrm{cm}^{2}$. For incubations in our large bags, ratios of sample weight to surface area up to $111 \mathrm{mg} / \mathrm{cm}^{2}$ were not significantly different from those with $20 \mathrm{mg} / \mathrm{cm}^{2}$ (data not shown).

Chemically available Lys in the original SBM and residues after $12 \mathrm{~h}$ of ruminal incubation were measured in duplicate according to the 1-fluoro-2,4-dinitrobenzene (FDNB) procedure described by Carpenter (1960). Available Lys is defined as units whose $\varepsilon$-amino groups are free and undergo a Sanger reaction with FDNB to form dinitrophenyl-Lys (Carpenter, 1960). Units whose $\varepsilon$-amino groups are bound to other groups will not react with FDNB and are therefore considered to be nutritionally unavailable. A standard curve was established by using $0,0.053,0.105$, and $0.210 \mathrm{mg}$ of dinitrophenyl-Lys (mono-6- $\mathrm{N}$-dinitrophenyl-Lys $\cdot \mathrm{H}$ $\mathrm{Cl} \cdot \mathrm{H}_{2} \mathrm{O}$; Sigma, St. Louis, MO). A linear standard curve was used to calculate available Lys in the sample, which was corrected for loss during acid hydrolysis. To correct for acid-hydrolysis loss, the recovery of a known amount $(4.15 \mathrm{mg})$ of the standard added to samples before acid hydrolysis was determined. The recovery was measured in 4 samples (duplicates of original and ruminal residuals of YSBM) and averaged $83 \%$.

Statistical Analyses. Data from the standard chick growth study were analyzed statistically by using PROC MIXED of SAS (SAS System for Windows, Release 8.1, SAS Inst. Inc.) as a randomized completeblock design. The model contained the effects of treatment and block. Linear and quadratic effects of SSBM treatments $(20,23,26$, and $29 \%)$ were tested by using single-degree-of-freedom contrasts. Original SBM were compared with ruminal residuals of SBM by using $t$ tests. Within-group (original and in situ residues) pairwise $t$-tests among all 4 products were used to separate means.

\section{RESULTS AND DISCUSSION}

\section{Experiment 1: Production Study}

The nutrient composition of dietary ingredients is presented in Table 4. The CP, NDF, and ADF contents (DM basis) of alfalfa, corn silage, and cottonseed were comparable to those reported by the NRC (2001). Diets contained an average of $16.9 \% \mathrm{CP}$ (DM basis) and were formulated to be isonitrogenous (Table 1).

The chemical composition of SBM products is presented in Table 2. Crude protein contents of SSBM and ESBM were comparable to published values (NRC, 
Table 4. Nutrient composition of dietary ingredients (experiment 1)

\begin{tabular}{lrcr}
\hline Nutrient & CP & NDF & ADF \\
\cline { 2 - 4 } & & \% of DM & \\
\cline { 2 - 4 } Alfalfa hay & 21.3 & 40.1 & 27.1 \\
Corn silage & 8.7 & 45.7 & 25.8 \\
Cottonseed & 22.1 & 46.0 & 33.5 \\
Grain mix & & & \\
SSBM & 15.7 & 18.3 & 9.7 \\
YSBM & 15.7 & 21.0 & 9.4 \\
ESBM & 15.5 & 19.6 & 10.2 \\
LSBM & 16.8 & 18.0 & 8.0 \\
\hline
\end{tabular}

${ }^{1}$ Included all dietary ingredients except alfalfa hay, corn silage, and whole cottonseed. See Table 1 for composition. SSBM = diet containing solvent SBM; YSBM = diet containing SSBM treated with 0.05\% baker's yeast (Saccharomyces cerevisiae) and steeped for 10 min at $30^{\circ} \mathrm{C}$ before toasting at $100^{\circ} \mathrm{C} ; \mathrm{ESBM}=$ diet containing expeller SBM; LSBM = diet containing lignosulfonate-treated SBM.

2001) and CP of LSBM was comparable to that reported by Mansfield and Stern (1994). Crude protein contents of SSBM and YSBM were nearly identical, as expected, because they were from the same source. The NDF and ADF contents of SSBM were comparable to those reported by the NRC (2001), although our ESBM had somewhat less NDF content than that reported by the NRC (2001; 13 vs. $22 \%$ ). The NDF content of LSBM was comparable to that reported by Mansfield and Stern (1994), although our LSBM had larger ADF values (11 vs. 3\%). Ether extracts of SSBM and ESBM were similar to the NRC (2001) values. The NDIN of SSBM generally was larger ( 12 vs. $1 \%$ of total N), and the NDIN for ESBM was smaller (8 vs. 21\%), than the NRC (2001) values. Both YSBM (42\%) and LSBM (29\%) contained substantially greater amounts of NDIN than did SSBM (11\%) or ESBM (8\%). Our ADIN values for SSBM and ESBM were larger than the NRC (2001) values (5.7 vs. $0.8 \%$ for SSBM and 4.2 vs. $0.8 \%$ for ESBM).

The AA profiles (Table 2) of SSBM, ESBM, and LSBM were comparable to those reported by the NRC (2001). The Lys contents, as a percentage of $\mathrm{CP}$, were greater for our SBM products than the NRC (2001) values (7.6 vs. $6.3 \%$ for SSBM, 7.6 vs. $6.3 \%$ for ESBM, and 6.7 vs. $5.8 \%$ for LSBM). Individual AA contents of the 4 SBM products were very similar, except for Lys. Lysine contents in SSBM and ESBM (7.6\%) were greater than those in YSBM (6.2\%) or LSBM (6.7\%), likely due to more cross-linked Lys in YSBM and LSBM that was not measured in our assay.

The effects of dietary treatments on cow performance are presented in Table 5. There were no significant effects of dietary treatments on DMI, BW gain, milk and component yields, and efficiency of milk production. We purposefully formulated the SSBM and ESBM diets to be sufficient in RDP, but deficient in RUP supply, and MP supply was designed to be inadequate to support production of $40.8 \mathrm{~kg} / \mathrm{d}$ of milk (Table 6 ), on the basis of evaluation with the NRC (2001) guidelines. For these evaluations, we used our measured values for protein fractions (Table 7). The NRC (2001) predicted, based on milk production at the beginning of the study ( 40.8 $\mathrm{kg} / \mathrm{d})$ and the predicted DMI $(25.5 \mathrm{~kg} / \mathrm{d})$, that the SSBM and ESBM diets were 181 and $169 \mathrm{~g} / \mathrm{d}$ deficient in RUP supply and 145 and $134 \mathrm{~g} / \mathrm{d}$ deficient in MP supply, respectively (Table 6). Thus, increasing the RUP supply by replacing SSBM with YSBM or LSBM could improve cow performance. At the end of the study, diets were reevaluated by using the actual DMI (average of 27.3 $\mathrm{kg} / \mathrm{d}$ ) and milk production (average of $33.6 \mathrm{~kg} / \mathrm{d}$ ), and all diets (including SSBM and ESBM) were found to be adequate in RUP and MP supply to support the actual amount of milk produced (Table 6). This might explain the lack of response to changes in RUP supply.

Responses of dairy cows to supplemental RUP within the literature have been inconsistent because of numerous factors. Santos et al. (1998) reported that, in most instances, replacing SSBM with protected (chemically treated, heated, or expeller) SBM did not improve cow performance; protected SBM increased milk production in only 6 of 29 comparisons, and it decreased milk protein contents in 8 of 29 comparisons. The authors partly attributed the lack of response to increased RUP supply to the fact that control diets provided sufficient RUP. Ipharraguerre and Clark (2005) reviewed the effect of supplemental RUP on the performance of dairy cows and demonstrated that replacing untreated with protected SBM (37 comparisons) increased milk yield only slightly (average of $<3 \%$ increase, range of 1.5 to $4.5 \%$ ), with decreased milk protein concentration attributable to dilution, resulting in similar milk protein yields.

Olmos Colmenero and Broderick (2006) demonstrated that $16.5 \% \mathrm{CP}$ in diets based on corn silage and alfalfa silage (50\% of DM; $1: 1$ ) was adequate to support maximal milk and protein yields in midlactation dairy cows producing approximately $40 \mathrm{~kg} / \mathrm{d}$ milk. They did not observe an advantage from increasing the $\mathrm{CP}$ of the diet to 17.9 or $19.4 \%$ by increasing dietary SSBM. When the diets of Olmos Colmenero and Broderick (2006) were evaluated by using NRC (2001) values, the data suggested no advantage of increasing the RDP and RUP supply above 11.0 and $5.5 \%$ of DM, respectively. Our control diet contained 11.3 and $5.5 \%$ of $\mathrm{DM}$ as RDP and RUP, respectively. Other researchers also did not observe improvements in milk and protein productions when dietary CP increased from 16.1 to $18.9 \%$ (Leonardi et al., 2003), from 16.5 to $18.5 \%$ (Cunningham et al., 1996), or from 16.7 to $18.4 \%$ (Broderick, 2003).

Armentano et al. (1993), Grummer et al. (1996), and Santos et al. (1998) suggested that better-producing cows ( $>30 \mathrm{~kg} / \mathrm{d}$, Armentano et al., 1993, and Santos et 
Table 5. Effect of soybean (SBM) products on performance of dairy cows (experiment 1)

\begin{tabular}{lcccccc}
\hline & \multicolumn{7}{c}{ Treatment $^{1}$} & & \\
\cline { 2 - 5 } Item & SSBM & YSBM & ESBM & LSBM & SEM & $P$-value \\
\hline BW change, kg/28 d & -0.9 & 3.3 & 4.8 & -2.8 & 4.2 & 0.57 \\
BCS change & 0.20 & -0.11 & 0.01 & 0.01 & 0.06 & 0.20 \\
DMI, kg/d & 26.9 & 27.2 & 27.3 & 27.6 & 0.53 & 0.83 \\
Milk, kg/d & 33.0 & 33.6 & 34.2 & 33.6 & 0.37 & 0.25 \\
4\% FCM, kg/d & 30.8 & 30.8 & 31.7 & 31.1 & 0.52 & 0.56 \\
ECM, kg/d & 33.2 & 33.3 & 34.3 & 33.7 & 0.52 & 0.49 \\
Milk:DMI & 1.219 & 1.235 & 1.245 & 1.223 & 0.026 & 0.90 \\
FCM:DMI & 1.139 & 1.134 & 1.155 & 1.133 & 0.039 & 0.97 \\
ECM:DMI & 1.231 & 1.227 & 1.250 & 1.226 & 0.040 & 0.97 \\
Protein, \% & 3.12 & 3.07 & 3.11 & 3.11 & 0.028 & 0.68 \\
Fat, \% & 3.59 & 3.48 & 3.54 & 3.55 & 0.070 & 0.73 \\
Lactose, \% & 4.64 & 4.68 & 4.67 & 4.65 & 0.026 & 0.66 \\
SNF, \% & 8.64 & 8.64 & 8.71 & 8.68 & 0.026 & 0.25 \\
Protein, kg/d & 1.012 & 1.020 & 1.050 & 1.035 & 0.013 & 0.27 \\
Fat, kg/d & 1.172 & 1.157 & 1.204 & 1.176 & 0.029 & 0.72 \\
Lactose, kg/d & 1.537 & 1.576 & 1.605 & 1.567 & 0.017 & 0.13 \\
SNF, kg/d & 2.841 & 2.898 & 2.970 & 2.910 & 0.029 & 0.10 \\
SCC & 586 & 618 & 452 & 705 & 82 & 0.28 \\
MUN, mg/dL & 15.0 & 15.3 & 15.2 & 14.5 & 0.34 & 0.42 \\
\hline
\end{tabular}

${ }^{1}$ SSBM $=$ solvent SBM; YSBM = SSBM treated with $0.05 \%$ baker's yeast (Saccharomyces cerevisiae) and steeped for $10 \mathrm{~min}$ at $30^{\circ} \mathrm{C}$ before toasting at $100^{\circ} \mathrm{C}$; ESBM = expeller SBM; LSBM = lignosulfonate-treated SBM.

Table 6. Diet evaluation (experiment 1$)^{1}$

\begin{tabular}{lrrrr}
\hline & \multicolumn{4}{c}{ Treatment $^{2}$} \\
\cline { 2 - 5 } Item & SSBM & YSBM & ESBM & LSBM \\
\hline$n_{\text {Initial }}^{3}$ & & & \\
RDP & & & \\
Required & 2,516 & 2,491 & 2,506 & 2,505 \\
Supplied & 3,098 & 2,816 & 3,024 & 2,787 \\
Balance & 581 & 324 & 518 & 282 \\
RUP & & & & \\
Required & 1,629 & 1,616 & 1,645 & 1,644 \\
Supplied & 1,448 & 1,660 & 1,476 & 1,647 \\
Balance & -181 & 44 & -169 & 3 \\
MP balance & -145 & 35 & -134 & 2 \\
Final & & & & \\
RDP & & & & \\
Required & 2,634 & 2,630 & 2,633 & 2,631 \\
Supplied & 3,250 & 2,981 & 3,186 & 2,935 \\
Balance & 616 & 350 & 553 & 304 \\
RUP & & & & \\
Required & 1,143 & 1,184 & 1,211 & 1,210 \\
Supplied & 1,549 & 1,790 & 1,586 & 1,763 \\
Balance & 406 & 606 & 375 & 552 \\
MP balance & 325 & 481 & 297 & 438 \\
\hline 1Accoryyy
\end{tabular}

\footnotetext{
${ }^{1}$ According to the NRC (2001).

${ }^{2} \mathrm{SBM}=$ soybean meal; $\mathrm{SSBM}=$ solvent $\mathrm{SBM} ; \mathrm{YSBM}=\mathrm{SSBM}$ treated with $0.05 \%$ baker's yeast (Saccharomyces cerevisiae) and steeped for $10 \mathrm{~min}$ at $30^{\circ} \mathrm{C}$ before toasting at $100^{\circ} \mathrm{C}$; ESBM $=$ expeller SBM; LSBM = lignosulfonate-treated SBM.

${ }^{3}$ Evaluated at the beginning of the study, based on initial milk production $(40.8 \mathrm{~kg} / \mathrm{d})$ and estimated intakes $(25 \mathrm{~kg} / \mathrm{d})$.

${ }^{4}$ Evaluated at the end of the study, based on the actual average milk production during the study $(34 \mathrm{~kg} / \mathrm{d})$ and actual intake (Table $5)$.
}

Journal of Dairy Science Vol. 90 No. 10, 2007 al., 1998; $>40$ kg/d, Grummer et al., 1996) are more likely to respond to supplemental RUP. In contrast, Dunlap et al. (2000) observed no interaction between production level and response to supplemental RUP. Dunlap et al. (2000) suggested that their diets may have been limited by energy supply for the high-producing cows in their study, which may have led to the lack of response to supplemental RUP. In our study, statistical analysis of data from only the cows with the greatest milk production failed to detect differences among treatments, suggesting that the lack of treatment response cannot be attributed solely to the modest production level of the cows.

Santos et al. (1998) suggested that the lack of response to increased RUP supply could be a result of depressed microbial protein synthesis as a consequence of a deficiency in the supply of RDP, because RUP sources were often added at the expense of RDP. All of our diets contained an adequate RDP supply to support cow requirements (Table 6).

High DMI by our cows $(27 \mathrm{~kg} / \mathrm{d})$ may have supported microbial protein supplies to the small intestine, resulting in little need for supplemental RUP. Replacing SSBM with heated whole soybeans did not improve performance in early-lactating dairy cows (Pires et al., 1996); the authors partly explained their observations as being a result of high DMI (24 kg/d). High DMI (24 to $25 \mathrm{~kg} / \mathrm{d}$ ) also has been used as an explanation for a lack of response to supplemental RUP (Broderick et 
Table 7. In situ protein degradation kinetics of soybean meal (SBM) products (experiment 2)

\begin{tabular}{|c|c|c|c|c|c|c|}
\hline \multirow[b]{2}{*}{ Item } & \multicolumn{4}{|c|}{ SBM product ${ }^{1}$} & \multirow[b]{2}{*}{ SEM } & \multirow[b]{2}{*}{$P$-value } \\
\hline & SSBM & YSBM & ESBM & LSBM & & \\
\hline \multicolumn{7}{|l|}{ Fraction, \% } \\
\hline $\mathrm{A}^{2}$ & 21 & 11 & 25 & 7 & 7.3 & 0.22 \\
\hline $\mathrm{B}^{3}$ & 78 & 89 & 70 & 61 & 22 & 0.67 \\
\hline $\mathrm{C}^{4}$ & 0 & 0 & 4 & 31 & 18 & 0.41 \\
\hline $\mathrm{k}_{\mathrm{B}},{ }^{5} \% / \mathrm{h}$ & 3.8 & 1.1 & 2.6 & 2.0 & 0.87 & 0.16 \\
\hline 16-h RUN, ${ }^{6} \%$ & $42^{\mathrm{c}}$ & $75^{\mathrm{a}}$ & $51^{\mathrm{bc}}$ & $78^{\mathrm{a}}$ & 2.1 & $<0.01$ \\
\hline 16-h RUN, ${ }^{7} \%$ & $50^{c}$ & $78^{\mathrm{a}}$ & $56^{\mathrm{bc}}$ & $81^{\mathrm{a}}$ & 4.5 & 0.01 \\
\hline Model RUN, $8 \%$ & $50^{\mathrm{d}}$ & $77^{\mathrm{b}}$ & $56^{\mathrm{c}}$ & $80^{\mathrm{a}}$ & 0.6 & $<0.01$ \\
\hline \multicolumn{7}{|c|}{${ }^{a-d}$ Values in the same row not bearing a common superscript letter differ $(P<0.05)$} \\
\hline \multicolumn{7}{|c|}{$\begin{array}{l}{ }^{1} \mathrm{SSBM}=\text { solvent } \mathrm{SBM} \text {; YSBM }=\mathrm{SSBM} \text { treated with } 0.05 \% \text { baker's yeast (Saccharomyces cerevisiae) } \text { and } \\
\text { steeped for } 10 \text { min at } 30^{\circ} \mathrm{C} \text { before toasting at } 100^{\circ} \mathrm{C} \text {; ESBM = expeller SBM; LSBM = lignosulfonate-treated } \\
\text { SBM. }\end{array}$} \\
\hline \multicolumn{7}{|c|}{${ }^{2}$ Instantly degraded N. } \\
\hline \multicolumn{7}{|c|}{${ }^{3}$ Slowly degraded protein fraction. } \\
\hline \multicolumn{7}{|c|}{${ }^{4}$ Completely undegradable protein fraction. } \\
\hline \multicolumn{7}{|c|}{${ }^{5}$ Degradation rate of fraction $\mathrm{B}$. } \\
\hline \multicolumn{7}{|c|}{$\begin{array}{l}{ }^{6} \text { Ruminally undegradable } N(\text { RUN }) \text { estimated by using fractions } A, B, C \text {, and } k_{B} \text { for each SBM as: RUN }= \\
\{B \times[\exp (-k \times t)]+C\} \text { for } t=16 \mathrm{~h} \text {. }\end{array}$} \\
\hline \multicolumn{7}{|c|}{${ }^{7}$ Ruminally undegradable $\mathrm{N}$ (RUN) measured as residual $\mathrm{N}$ after $16-\mathrm{h}$ ruminal incubation. } \\
\hline $\begin{array}{l}{ }^{8} \text { Ruminally un } \\
\mathrm{B} \times\left[7 /\left(7+\mathrm{k}_{\mathrm{B}}\right)\right]\end{array}$ & able $\mathrm{N}($ & estimate & g fractior & $3, \mathrm{C}$, and & & \\
\hline
\end{tabular}

al., 1990; Polan et al., 1997). Broderick et al. (1990) demonstrated that the increase in production of milk and milk components with supplemental RUP (ESBM) was greater at low DMI $(20 \mathrm{~kg} / \mathrm{d})$ than at intermediate DMI (22 kg/d), with no increase at high DMI $(24 \mathrm{~kg} / \mathrm{d})$. The authors attributed the lack of response to RUP supplementation at high DMI to the large supply of microbial protein.

Replacing SSBM with ESBM increased milk production in early-lactation dairy cows fed diets with alfalfa silage as the only forage source (Broderick et al., 1990). Dairy cows fed diets based on alfalfa silage were more likely to benefit from supplemental RUP than those fed diets based on corn silage (Voss et al., 1988). Replacing SSBM with heated whole soybeans also improved milk production in cows fed diets based on alfalfa silage (Faldet and Satter, 1991; Knapp et al., 1991), but not in diets based on corn silage (Bernard, 1990). Our forage sources (corn silage and alfalfa hay) likely would provide more RUP than alfalfa silage.

The effects of dietary treatments on plasma metabolites are presented in Table 8 . There were no effects $(P$ $\geq 0.30$ ) of dietary treatment on plasma glucose or urea concentrations. Because diets were isonitrogenous, the similarity among treatments for plasma urea was not surprising, and agrees well with the similarity among treatments for MUN (Table 5). In general, total AA, EAA, nonessential AA, branched-chain AA, individual AA concentrations (except Leu), and individual AA as a percentage of total AA (except Leu; data not shown) were not affected $(P \geq 0.20)$ by dietary treatments. The lack of effects of dietary treatments on plasma AA could be explained by only modest differences among treatments in the supply of absorbable AA to the small intestine. Our production data (Table 5) indicated that AA requirements were met by all of our diets, so increases in plasma AA could be expected in response to increases in their supplies. Although YSBM and LSBM contained more RUP than did SSBM and ESBM (experiment 2), they likely failed to greatly increase the supply of absorbed AA.

Although the effects were not significant, there were numerically higher plasma concentrations of branchedchain AA (particularly Leu), which are not usually susceptible to heat damage, for YSBM and LSBM. For Lys, however, which is susceptible to heat damage, YSBM and LSBM did not lead to changes in plasma concentrations.

\section{Experiment 2: In Situ Protein Degradability and Intestinal Digestibility of RUN}

Residual $\mathrm{N}$ remaining after ruminal incubation (RUN) of SBM products for different incubation times is presented in Table 9. At each time point, RUN was greater $(P<0.05)$ for YSBM and LSBM than for SSBM or ESBM, with no differences between YSBM and LSBM or between SSBM and ESBM, except at $0 \mathrm{~h}$, at which point SSBM and YSBM did not differ, and at 24 $h$, at which point RUN for ESBM was greater than that 
Table 8. Effect of soybean (SBM) products on plasma metabolite concentrations of dairy cows (experiment 1)

\begin{tabular}{|c|c|c|c|c|c|c|}
\hline \multirow[b]{2}{*}{ Item } & \multicolumn{4}{|c|}{ Treatment $^{1}$} & \multirow[b]{2}{*}{ SEM } & \multirow[b]{2}{*}{$P$-value } \\
\hline & SSBM & YSBM & ESBM & LSBM & & \\
\hline & & & & - & & \\
\hline Glucose & 3.67 & 3.62 & 3.63 & 3.62 & 0.02 & 0.31 \\
\hline Urea & 5.56 & 5.90 & 5.89 & 5.89 & 0.13 & 0.30 \\
\hline Ala & 234 & 225 & 232 & 239 & 5.5 & 0.42 \\
\hline Arg & 90 & 86 & 94 & 83 & 4.6 & 0.41 \\
\hline Asn & 29 & 30 & 34 & 30 & 1.4 & 0.23 \\
\hline Asp & 16 & 15 & 14 & 14 & 1.7 & 0.84 \\
\hline Citrulline & 82 & 92 & 81 & 86 & 4.9 & 0.45 \\
\hline Glu & 107 & 98 & 113 & 107 & 4.6 & 0.28 \\
\hline Gln & 163 & 168 & 170 & 173 & 8.0 & 0.84 \\
\hline Gly & 242 & 226 & 250 & 235 & 11.4 & 0.53 \\
\hline His & 37 & 35 & 35 & 36 & 3.7 & 0.98 \\
\hline Ile & 109 & 127 & 121 & 126 & 8.5 & 0.46 \\
\hline Leu & 130 & 151 & 131 & 151 & 5.5 & 0.06 \\
\hline Lys & 89 & 91 & 99 & 88 & 4.3 & 0.33 \\
\hline Met & 17 & 20 & 19 & 21 & 1.3 & 0.20 \\
\hline Ornithine & 63 & 67 & 67 & 63 & 4.2 & 0.78 \\
\hline Phe & 48 & 47 & 42 & 48 & 5.2 & 0.80 \\
\hline Ser & 88 & 90 & 90 & 88 & 2.3 & 0.83 \\
\hline Taurine & 46 & 44 & 52 & 48 & 3.6 & 0.51 \\
\hline Thr & 78 & 73 & 81 & 79 & 2.9 & 0.30 \\
\hline Trp & 23 & 25 & 24 & 23 & 2.6 & 0.96 \\
\hline Tyr & 46 & 46 & 45 & 49 & 4.1 & 0.94 \\
\hline Val & 245 & 284 & 245 & 272 & 13.7 & 0.20 \\
\hline Branched-chain $\mathrm{AA}^{2}$ & 483 & 562 & 497 & 548 & 24.5 & 0.16 \\
\hline Essential $\mathrm{AA}^{3}$ & 864 & 939 & 891 & 926 & 26.9 & 0.29 \\
\hline Nonessential AA ${ }^{4}$ & 1,115 & 1,102 & 1,148 & 1,130 & 18.8 & 0.42 \\
\hline Total AA & 1,979 & 2,041 & 2,038 & 2,057 & 39.2 & 0.55 \\
\hline
\end{tabular}

${ }^{1}$ SSBM $=$ solvent SBM; YSBM = SSBM treated with $0.05 \%$ baker's yeast (Saccharomyces cerevisiae) and steeped for $10 \mathrm{~min}$ at $30^{\circ} \mathrm{C}$ before toasting at $100^{\circ} \mathrm{C}$; $\mathrm{ESBM}=$ expeller SBM; LSBM = lignosulfonate-treated SBM.

${ }^{2}$ Sum of Leu, Ile, and Val.

${ }^{3}$ Sum of His, Ile, Leu, Lys, Met, Phe, Thr, Trp, Val, and Arg.

${ }^{4}$ Total AA minus EAA.

Table 9. Residual N remaining after ruminal incubation of soybean meal (SBM) products at different time points (experiment 2$)^{1}$

\begin{tabular}{lcccc}
\hline & \multicolumn{4}{c}{ Soybean product ${ }^{2}$} \\
\cline { 2 - 5 } Time, h & SSBM & YSBM & ESBM & LSBM \\
\hline 0 & $77.7^{\mathrm{bc}}$ & $84.4^{\mathrm{ab}}$ & $67.3^{\mathrm{c}}$ & $92.0^{\mathrm{a}}$ \\
2 & $66.0^{\mathrm{b}}$ & $86.4^{\mathrm{a}}$ & $72.1^{\mathrm{b}}$ & $89.8^{\mathrm{a}}$ \\
4 & $67.8^{\mathrm{b}}$ & $85.8^{\mathrm{a}}$ & $68.7^{\mathrm{b}}$ & $87.7^{\mathrm{a}}$ \\
8 & $64.3^{\mathrm{b}}$ & $83.5^{\mathrm{a}}$ & $68.5^{\mathrm{b}}$ & $88.8^{\mathrm{a}}$ \\
16 & $49.8^{\mathrm{b}}$ & $78.5^{\mathrm{a}}$ & $56.2^{\mathrm{b}}$ & $80.5^{\mathrm{a}}$ \\
24 & $25.6^{\mathrm{c}}$ & $65.8^{\mathrm{a}}$ & $41.0^{\mathrm{b}}$ & $67.9^{\mathrm{a}}$ \\
48 & $8.2^{\mathrm{b}}$ & $51.5^{\mathrm{a}}$ & $18.5^{\mathrm{b}}$ & $60.2^{\mathrm{a}}$ \\
\hline
\end{tabular}

${ }^{a-c}$ Values in the same row not bearing a common superscript letter differ $(P<0.05)$.

${ }^{1} \mathrm{SEM}=4.6 ; \mathrm{LSD}=13.3$.

${ }^{2} \mathrm{SSBM}=$ solvent SBM; YSBM = SSBM treated with $0.05 \%$ baker's yeast (Saccharomyces cerevisiae) and steeped for $10 \mathrm{~min}$ at $30^{\circ} \mathrm{C}$ before toasting at $100^{\circ} \mathrm{C} ; \mathrm{ESBM}=$ expeller $\mathrm{SBM} ; \mathrm{LSBM}=$ lignosulfonate-treated SBM. for SSBM. The RUN declined more rapidly over time for SSBM and ESBM than for YSBM and LSBM (treatment $\times$ time, $P<0.05$ ).

Kinetic data for in situ CP degradation for the SBM products are presented in Table 7. Although it was not statistically different $(P \geq 0.16)$, likely because of the small number of replications (2 per incubation time per steer), differences among SBM products in CP degradation kinetics were observable. For example, YSBM and LSBM had greater RUN contents than did SSBM or ESBM, predominantly as a result of lesser $\mathrm{k}_{\mathrm{B}}$ (YSBM) or greater fraction C (LSBM).

The RUN contents of SBM products estimated by using the predicted model, based on estimated A, B, C, and $k_{B}$ values in Table 7 , were comparable to those measured by using the single 16 -h time point. Our measured value for RUN (16-h residue) for ESBM was smaller than the NRC (2001) value (56 vs. $69 \%$ ), but 
Table 10. Intestinal digestibility of original and ruminally undegraded $\mathrm{N}$ fraction of soybean meal (SBM) products (experiment 2)

\begin{tabular}{lcccccrr}
\hline & \multicolumn{5}{c}{ SBM product $^{1}$} & & \\
\cline { 2 - 5 } Item & SSBM & YSBM & ESBM & LSBM & SEM & $P$-value \\
\hline RUN, ${ }^{2} \%$ & $47.7^{\mathrm{c}}$ & $83.0^{\mathrm{a}}$ & $55.5^{\mathrm{b}}$ & $81.5^{\mathrm{a}}$ & 1.4 & $<0.01$ \\
Intestinal digestibility, \% of RUN & 82.5 & 80.0 & 85.9 & 78.5 & 2.3 & 0.29 \\
Intestinal availability, ${ }^{3} \%$ of ingredient $\mathrm{N}$ & $39.3^{\mathrm{c}}$ & $66.4^{\mathrm{a}}$ & $47.7^{\mathrm{b}}$ & $64.0^{\mathrm{a}}$ & 2.1 & $<0.01$ \\
\hline
\end{tabular}

${ }^{\mathrm{a}-c}$ Values in the same row without a common superscript letter are different $(P \leq 0.05)$.

${ }^{1} \mathrm{SSBM}=$ solvent SBM; YSBM = SSBM treated with $0.05 \%$ baker's yeast (Saccharomyces cerevisiae) and steeped for $10 \mathrm{~min}$ at $30^{\circ} \mathrm{C}$ before toasting at $100^{\circ} \mathrm{C}$; ESBM = expeller SBM; LSBM = lignosulfonate-treated SBM.

${ }^{2}$ Ruminally undegradable $\mathrm{N}$ based on 16 -h ruminal incubation in situ.

${ }^{3} \mathrm{RUN} \times$ intestinal digestibility of RUN.

that for LSBM was comparable to the NRC (2001) value (81 vs. $79 \%$ ). Assuming a passage rate of $7 \% / \mathrm{h}$, our measured RUN content for SSBM (50\%) was somewhat more than the $43 \%$ value reported by the NRC (2001). This likely contributed to our SSBM diet providing adequate RUP to the cows, thereby preventing a response to supplemental RUP from the other SBM products.

Intestinal digestibilities of RUN from SBM products are presented in Table 10. There were no differences $(P=0.22)$ among SBM products for intestinal digestibility of RUN, which averaged $82 \%$. Because there was more RUN in YSBM (83\%) and LSBM (81\%) than in $\operatorname{SSBM}(48 \%)$ and $\operatorname{ESBM}(55 \%)$, the proportions of ingredient $\mathrm{N}$ that were available postruminally were greater for YSBM (66\%) and LSBM (64\%) than for SSBM (39\%) or ESBM (48\%). The NRC (2001) has assigned a single value of $93 \%$ for intestinal digestibility for SSBM, ESBM, and LSBM.

Data from experiment 2 alone indicated that YSBM or LSBM could support higher performance of cattle, compared with SSBM or ESBM, if the RUP supply was limiting. Our data from experiment 3 , however, indicate that the lack of differences among SBM sources in intestinal digestion, as evaluated by the 3-step procedure, is not completely correct, at least for Lys availability.

\section{Experiment 3: Lys Bioavailability}

The performance of chicks fed different SBM products is presented in Table 11 and Figure 1. Chick performance [DMI, ADG, and gain:feed ratio (G:F)] was linearly improved $(P<0.05)$ with increasing protein supply from SSBM (Figure 1), indicating that chick performance was, as intended, limited by protein supply. In addition, supplementing Lys to the diet containing $26 \%$ SSBM resulted in improved $(P<0.05)$ performance (DMI, ADG, and G:F), compared with the 26\% SSBM treatment. This indicates that chick performance was indeed limited by Lys supply, and our study provided a comparison of the relative Lys bioavailabilities in SBM products.

When original SBM products were used to generate the diets, SSBM and ESBM resulted in similar performance (DMI, ADG, G:F), but they yielded better ( $P$ $<0.05$ ) performance than YSBM and LSBM. Feeding SSBM or ESBM resulted, respectively, in 21 and $18 \%$ more DMI, 29 and $26 \%$ faster ADG, and 6 and $7 \%$ more efficient diet utilization compared with LSBM. This indicates that Lys was more available for growth in SSBM and ESBM than in YSBM and LSBM. Feeding YSBM resulted in 25\% less DMI, 31\% slower growth, and $8 \%$ less efficient utilization, compared with feeding LSBM, suggesting that Lys was less available for growth in YSBM than in LSBM. This might be, in part, due to "overprotection" of YSBM by applying heat in the presence of reducing sugars, which might have led to deleterious effects on Lys availability as a result of Maillard product formation.

Feeding in situ residues of SSBM, ESBM, or LSBM resulted in similar performance (DMI, $\mathrm{ADG}$, and G:F) but $39 \%$ more DMI, $66 \%$ faster ADG, and $20 \%$ better G:F compared with feeding in situ residues of YSBM. If a prediction of performance was based on total Lys content alone (Table 12), feeding in situ residues of LSBM would be expected to result in worse chick performance than feeding SSBM or ESBM, simply because LSBM (5.8\% of CP) had less total Lys content than did SSBM $(6.7 \%$ of CP) or ESBM (7.0\% of CP).

For each SBM product, we formulated 2 diets, 1 based on the original SBM product and the other containing residues from incubation in situ for $12 \mathrm{~h}$, to 1 ) simulate what actually occurred when SBM was fed to cattle, and 2) investigate whether in situ incubation is an important preceding step for evaluating intestinal digestion of SBM products. Using in situ residues for SSBM or ESBM yielded less $(P<0.05) \mathrm{DMI}$ and slower ADG, but more efficient G:F, compared with using the original SSBM and ESBM. This could be due to depressed chick 
Table 11. Performance of chicks fed original soybean meal (SBM) products or in situ residues of SBM products (experiment 3$)^{1}$

\begin{tabular}{|c|c|c|c|c|c|c|c|c|c|}
\hline \multirow[b]{2}{*}{ Item } & \multicolumn{4}{|c|}{ Original SBM products ${ }^{1}$} & \multicolumn{4}{|c|}{12 -h in situ residues ${ }^{1}$} & \multirow[b]{2}{*}{ SEM } \\
\hline & SSBM & YSBM & ESBM & LSBM & SSBM & YSBM & ESBM & LSBM & \\
\hline $\mathrm{n}$ & 4 & 4 & 4 & 4 & 4 & 4 & 4 & 4 & \\
\hline DMI, g/d & $18.31^{\mathrm{a}}$ & $11.36^{\mathrm{c}}$ & $17.90^{\mathrm{a}}$ & $15.13^{\mathrm{b}}$ & $14.72^{\mathrm{d}, \mathrm{z}}$ & $10.68^{\mathrm{e}}$ & $15.04^{\mathrm{d}, \mathrm{z}}$ & $14.56^{\mathrm{d}}$ & 0.40 \\
\hline $\mathrm{ADG}, \mathrm{g} / \mathrm{d}$ & $14.85^{\mathrm{a}}$ & $7.94^{\mathrm{c}}$ & $14.58^{\mathrm{a}}$ & $11.53^{\mathrm{b}}$ & $12.53^{\mathrm{d}, \mathrm{z}}$ & $7.60^{\mathrm{e}}$ & $12.95^{\mathrm{d}, \mathrm{z}}$ & $12.23^{\mathrm{d}}$ & 0.34 \\
\hline Gain:feed & $0.811^{\mathrm{a}}$ & $0.700^{\mathrm{c}}$ & $0.814^{\mathrm{a}}$ & $0.761^{\mathrm{b}}$ & $0.852^{\mathrm{d}, \mathrm{z}}$ & $0.711^{\mathrm{e}}$ & $0.861^{\mathrm{d}, \mathrm{z}}$ & $0.840^{\mathrm{d}, \mathrm{z}}$ & 0.01 \\
\hline
\end{tabular}

${ }^{\mathrm{a}-\mathrm{e}}$ Values within each category (original or residues) without a common superscript letter $\operatorname{differ}(P<0.05)$.

${ }^{z}$ Values differ from the original of the same SBM product $(P<0.05)$.

${ }^{1} \mathrm{SSBM}=$ solvent SBM; YSBM = SSBM treated with $0.05 \%$ baker's yeast (Saccharomyces cerevisiae) and steeped for $10 \mathrm{~min}$ at $30^{\circ} \mathrm{C}$ before toasting at $100^{\circ} \mathrm{C}$; ESBM = expeller SBM; LSBM = lignosulfonate-treated SBM. The SSBM diet contained 26\% SSBM, and the remaining diets were formulated to be isonitrogenous by removing all of the SSBM, adding an isonitrogenous amount of the alternative SBM, and varying the amount of cornstarch.

DMI as a result of poor palatability of the in situ residues, which is supported by the improved G:F. Chemically available Lys (\% of CP) for the original SSBM and ESBM was very similar to that of their corresponding in situ residues, and available Lys in LSBM was actually greater in the in situ residues than in the original product (Table 13). For YSBM, feeding either the original or in situ residues yielded a striking depression in chick performance. Chemically available Lys (Table 13), as a percentage of CP in original YSBM $(4.1 \%)$, was similar to that in in situ residues $(3.9 \%)$.

In general, using ruminal in situ residues or original SBM in the chick growth assay yielded similar ranking of SBM products in terms of Lys availability, except for LSBM, which led to worse performance than SSBM or ESBM when the original SBM products were compared, but equal performance when the in situ residues were compared. It is possible that some of the unavailable Lys in LSBM became available to the chicks after 12 $\mathrm{h}$ of ruminal incubation. This hypothesis agreed with our data showing that the chemically available Lys content (\% of CP) in the in situ residues from LSBM was greater than in the original LSBM, that chemically available Lys in the original LSBM was less than that in the original SSBM or ESBM, and that in situ residues of LSBM had available Lys comparable to in situ residues of SSBM or ESBM. Our data indicate that Lys availability in SBM products can be affected by ruminal incubation.

Data from experiment 2, that YSBM and LSBM had greater RUP contents than SSBM or ESBM, suggests that YSBM or LSBM could support higher performance of cattle compared with SSBM or ESBM if the total RUP supply was limiting. Data from this experiment, however, indicated that there were likely differences in Lys availability. We purposefully formulated the control diet offered to cows in experiment 1 to be limiting in RUP, specifically in Lys supply. When the Lys supply available to cows was estimated, by multiplying the available Lys content as a percentage of $\mathrm{CP}$ of the in situ residues (Table 13) by the 16-h RUP value (Table 7 ), available Lys supplied by the SSBM (2.1\%) was not very different from the amounts supplied by ESBM (1.9\%), YSBM $(2.4 \%)$, or LSBM (2.7\%). The fact that diets were not very different in available Lys supply could explain the lack of treatment differences in experiment 1 . It is also possible that our control diet might not have been limited by Lys supply.

The chemically available Lys contents in original SBM and in situ residues of SBM products are presented in Table 13. Chemically available Lys as a percentage of CP was greater for original $\operatorname{SSBM}(5.5 \%)$ and $\operatorname{ESBM}(5.3 \%)$ than for YSBM (4.1\%) or LSBM (4.3\%). In addition, when expressed as a percentage of total Lys, the chemically available Lys contents of SSBM (73\%) and ESBM $(70 \%)$ were greater than those of YSBM (66\%) or LSBM (63\%); these percentages are likely overestimates for YSBM and LSBM, in which total Lys content is perhaps an underestimate of the Lys present in those products before processing.

The chemically available Lys contents for in situ residues of SSBM (4.0\% of DM), ESBM (3.5\%), and LSBM $(3.7 \%)$ were comparable but were greater than that in YSBM (2.9\%), which agreed with chick performance data. When expressed as a percentage of $\mathrm{CP}$, in situ residues of SSBM (5.2\%), ESBM (5.3\%), and LSBM $(5.1 \%)$ were almost identical but were greater than that in YSBM (3.9\%). Because total Lys contents in in situ residues for YSBM (4.9\% of CP; Table 12) and LSBM $(5.8 \%)$ were less than that in residual SSBM $(6.7 \%)$ or ESBM (7.0\%), chemically available Lys as a percentage of total Lys was greater in in situ residues of YSBM (81\% of total Lys) and LSBM (87\%) than in those for SSBM (78\%) and ESBM (76\%).

Chemically available Lys contents as a percentage of DM were greater in in situ residues, compared with 

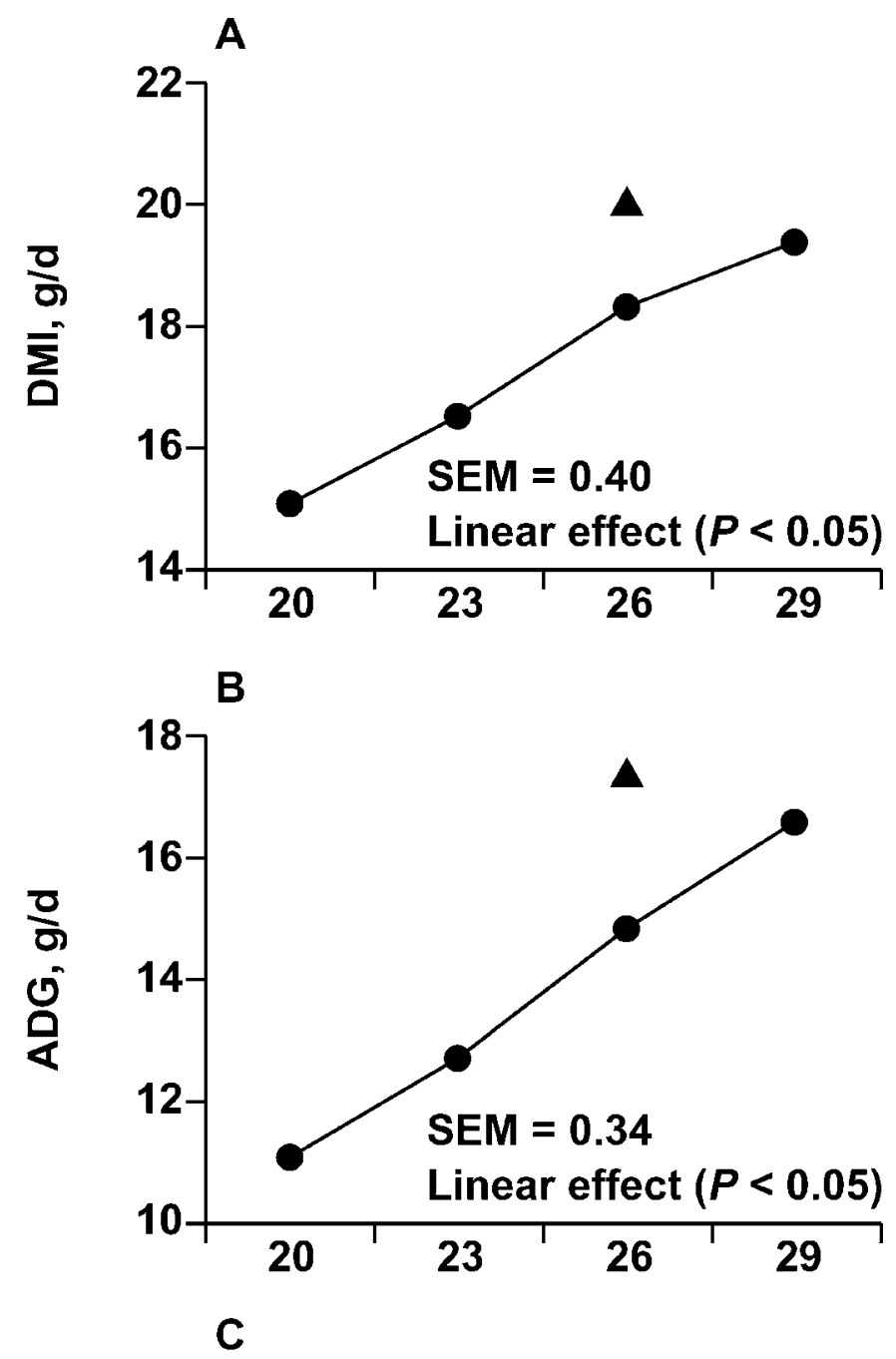

Table 12. Nutrient composition of in situ residues of soybean meal (SBM) products

\begin{tabular}{|c|c|c|c|c|}
\hline \multirow[b]{2}{*}{ Nutrient } & \multicolumn{4}{|c|}{ SBM product ${ }^{1}$} \\
\hline & SSBM & YSBM & ESBM & LSBM \\
\hline & $-\%$ & $\mathrm{M}(\%$ of $\mathrm{ol}$ & al CP reco & d) \\
\hline \multirow[t]{2}{*}{$\mathrm{CP}$} & $76.6(65)$ & $74.7(86)$ & $65.9(68)$ & $72.8(86)$ \\
\hline & \multicolumn{4}{|c|}{$\%$ of $\mathrm{CP}$ (\% of original $\mathrm{AA}$ recovered) } \\
\hline Ala & $4.2(65)$ & $4.1(82)$ & $4.3(67)$ & $4.1(85)$ \\
\hline Arg & $6.5(61)$ & $5.9(80)$ & $7.1(68)$ & 6.5 \\
\hline Asp & $11.0(62)$ & $10.6(80)$ & $11.0(67)$ & $10.6(82)$ \\
\hline Glu & $16.9(60)$ & $16.9(82)$ & $17.1(67)$ & 17.0 \\
\hline Gly & $4.2(61)$ & $3.9(73)$ & $4.3(63)$ & $4.0(77)$ \\
\hline His & $2.5(63)$ & $2.3(82)$ & $2.5(60)$ & $2.4(81)$ \\
\hline Ile & $5.7(69)$ & $5.7(88)$ & $5.6(74)$ & $5.5(89)$ \\
\hline Leu & $8.1(68)$ & $7.8(88)$ & $8.1(71)$ & $7.8(87)$ \\
\hline Lys & $6.7(58)$ & $4.9(67)$ & $7.0(63)$ & $5.8(74)$ \\
\hline Met & $1.1(78)$ & $1.1(85)$ & $1.1(90)$ & $1.1(95)$ \\
\hline Phe & $5.6(67)$ & $5.4(87)$ & $5.4(72)$ & $5.4(88)$ \\
\hline Ser & $5.1(65)$ & $4.8(81)$ & $5.3(75)$ & $5.0(83)$ \\
\hline Thr & $4.0(67)$ & $3.9(84)$ & $3.9(69)$ & $3.9(90)$ \\
\hline Tyr & 3.7 (71) & $3.7(90)$ & $3.7(80)$ & $3.8(95)$ \\
\hline Val & $5.3(65)$ & $5.1(82)$ & $5.2(67)$ & $5.0(85)$ \\
\hline
\end{tabular}

${ }^{1} \mathrm{SSBM}=$ solvent SBM; YSBM $=\mathrm{SSBM}$ treated with $0.05 \%$ baker's yeast (Saccharomyces cerevisiae) and steeped for $10 \mathrm{~min}$ at $30^{\circ} \mathrm{C}$ before toasting at $100^{\circ} \mathrm{C} ; \mathrm{ESBM}=$ expeller SBM; LSBM = lignosulfonate-treated SBM.

original SBM, likely as a result of greater CP contents in in situ residues than in original SBM. As a percentage of $\mathrm{CP}$, however, chemically available Lys contents in in situ residues were almost identical to the original SBM for the same product, except for LSBM. It is possible that some of the unavailable Lys in the original LSBM became available after ruminal incubation, resulting in a greater content of available Lys (5.1 vs. $4.3 \%$ ).

Table 13. Chemically available Lys of soybean meal (SBM) products (experiment 3)

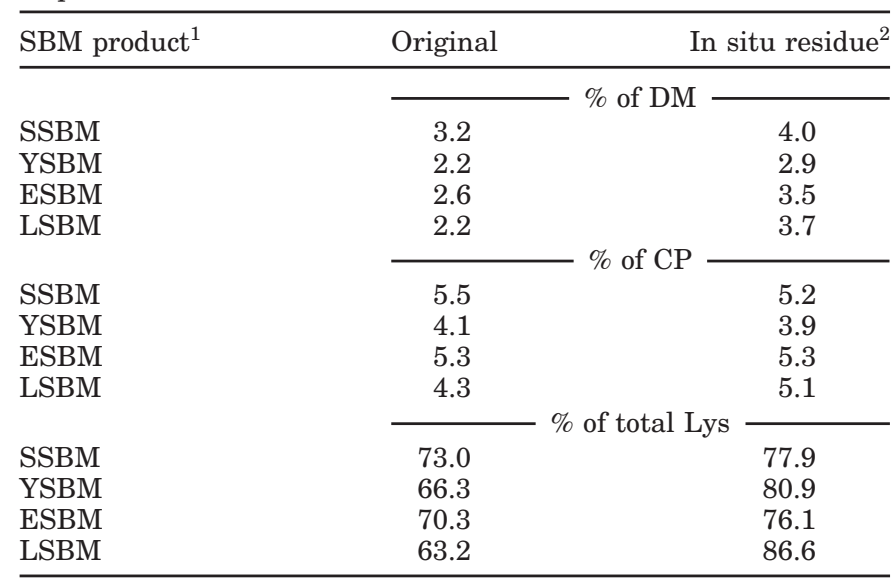

Figure 1. A) Dry matter intake, B) ADG, and C) gain:feed ratio for the solvent soybean meal standard curve () and for the diet with $0.15 \%$ added Lys $\cdot \mathrm{HCl}$ ( $\mathbf{\Delta}$; experiment 3 ).
${ }^{1} \mathrm{SSBM}=$ solvent SBM; YSBM $=$ SSBM treated with $0.05 \%$ baker's yeast (Saccharomyces cerevisiae) and steeped for $10 \mathrm{~min}$ at $30^{\circ} \mathrm{C}$ before toasting at $100^{\circ} \mathrm{C} ; \mathrm{ESBM}=$ expeller SBM; LSBM = lignosulfonate-treated SBM.

${ }^{2}$ Residue after 12 -h ruminal incubation in situ. 
It seems that application of heat to SBM during LSBM and YSBM manufacturing might decrease Lys availability. This would appear to be more of a problem during YSBM manufacturing than during LSBM manufacturing. It should be noted that SSBM and YSBM were from the same source, but LSBM was a commercial product and the SSBM used to produce it was unknown.

Amino acid composition of the in situ residues used to feed chicks is presented in Table 12. Although no statistical tests could be performed, concentrations of individual AA were similar among the 4 SBM products, except for Lys. Lysine concentrations in YSBM (4.9\% of CP) and LSBM (5.8\%) were less than those in SSBM $(6.7 \%)$ and ESBM (7.0\%), likely because of the greater cross-linked Lys in YSBM and LSBM. Individual AA were generally degraded within each SBM product to a similar extent during in situ incubation, except for Lys. As discussed for N, however, there were clear differences among SBM products. Others (Kerry et al., 1993; O’Mara et al., 1997; Tamminga, 1979) have reported differences in ruminal degradation among individual AA. For example, Met (Tamminga, 1979), Leu, and Ile (O'Mara et al., 1997) were the least degradable AA, and Glu (O'Mara et al., 1997) was the most degradable AA.

Across SBM products, Lys was the most degraded AA. O'Mara et al. (1997) and Lykos and Varga (1995) reported that Lys was one of the most degradable AA in SBM. Erasmus et al. (1994) also showed decreased Lys contents in SBM after exposure to in situ ruminal degradation. All AA in YSBM and LSBM were degraded less upon in situ incubation than were AA in SSBM or ESBM as a result of protection from ruminal degradation of YSBM and LSBM products. Kerry et al. (1993) demonstrated that replacing SSBM with heated SBM resulted in less degradation of dietary Arg, Ile, Phe, and Thr in steers.

Borucki Castro et al. (2007) extended the 3-step procedure of Calsamiglia and Stern (1995) for assessing intestinal digestion of $\mathrm{CP}$ in vitro to evaluate intestinal AA digestibility. They observed that Lys digestibility in in situ residues of various SBM products was greater than that of other AA, although the 3-step procedure has not been validated with regard to its ability to accurately assess intestinal digestion of individual AA. Our work with the 3-step procedure demonstrated no differences among SBM products in intestinal CP digestion, but we observed significantly impaired in vivo Lys availability in several of the products; this suggests that the 3-step procedure may not be appropriate for assessing availability of individual AA, particularly of Lys.

\section{CONCLUSIONS}

Treating SBM with lignosulfonate or yeast followed by heating, to induce nonenzymatic browning, was successful in protecting LSBM and YSBM from ruminal degradation. Thus, replacing SSBM with YSBM or LSBM increased the RUP supply. Dairy cows producing approximately $33 \mathrm{~kg}$ of milk/d and fed dietary RUP concentrations of $5.5 \%$ of DM did not benefit when SSBM was replaced by less degradable sources of SBM, likely because of the adequate RUP supply in the control diet or a lack of change in the supply of absorbable Lys (the AA predicted to be the most limiting in our diets). Processing of YSBM and LSBM seemed to decrease Lys bioavailability. The chemically available (FDNB) Lys procedure and a chick growth assay gave comparable results regarding Lys availability in SBM products, but using original SBM or SBM residues after in situ incubation in these procedures yielded different results, especially for LSBM. Thus, using in situ residues of SBM products in the chick growth assay to assess the impact of treating SBM on Lys bioavailability would be recommended, rather than using the original SBM.

\section{REFERENCES}

AOAC. 1984. Official Methods of Analysis. 12th ed. Assoc. Off. Analyt. Chem., Arlington, VA.

Armentano, L. E., S. J. Bertics, and J. Riesterer. 1993. Lack of response to addition of degradable protein to a low protein diet fed to midlactation dairy cows. J. Dairy Sci. 76:3755-3762.

Bernard, J. K. 1990. Effect of raw or roasted whole soybeans on digestibility of dietary nutrients and milk production of lactating dairy cows. J. Dairy Sci. 73:3231-3236.

Borucki Castro, S. I., L. E. Phillip, H. Lapierre, P. W. Jardon, and R. Berthiaume. 2007. Ruminal degradability and intestinal digestibility of protein and amino acids in treated soybean meal products. J. Dairy Sci. 90:810-822.

Broderick, G. A. 2003. Effects of varying dietary protein and energy levels on the production of lactating dairy cows. J. Dairy Sci. 86:1370-1381.

Broderick, G. A., D. B. Ricker, and L. S. Driver. 1990. Expeller soybean meal and corn by-products versus solvent soybean meal for lactating dairy cows fed alfalfa silage as a sole forage. J. Dairy Sci. 73:453-462.

Calsamiglia, S., and M. D. Stern. 1995. A three-step in vitro procedure for estimating intestinal digestion of protein in ruminants. J. Anim. Sci. 73:1459-1465.

Carpenter, K. J. 1960. The estimation of the available lysine in animal-protein foods. Biochem. J. 77:604-610.

Chandler, P. T. 1989. Achievement of optimum amino acid balance possible. Feedstuffs 61(26):14-25.

Coblentz, W. K., J. O. Fritz, R. C. Cochran, W. L. Rooney, and K. K. Bolsen. 1997. Protein degradation in response to spontaneous heating in alfalfa hay by in situ and ficin methods. J. Dairy Sci. 80:700-713.

Cunningham, K. D., M. J. Cecava, T. R. Johnson, and P. A. Ludden. 1996. Influence of source and amount of dietary protein on milk yield by cows in early lactation. J. Dairy Sci. 79:620-630.

Dunlap, T. F., R. A. Kohn, L. W. Douglass, and R. A. Erdman. 2000. Diets deficient in rumen undegraded protein did not depress milk production. J. Dairy Sci. 83:1806-1812. 
Erasmus, L. J., P. M. Botha, and C. W. Cruywagen. 1994. Amino acid profile and intestinal digestibility in dairy cows of rumenundegradable protein from various feedstuffs. J. Dairy Sci. 77:541-551.

Faldet, M. A., and L. D. Satter. 1991. Feeding heat-treated full fat soybeans to cows in early lactation. J. Dairy Sci. 74:3047-3054.

Faldet, M. A., L. D. Satter, and G. A. Broderick. 1992. Determining optimal heat treatment of soybeans by measuring available lysine chemically and biologically with rats to maximize protein utilization by ruminants. J. Nutr. 122:151-160.

Gochman, N., and J. M. Schmitz. 1972. Application of a new peroxide indicator reaction to the specific, automated determination of glucose with glucose oxidase. Clin. Chem. 18:943-950.

Grummer, R. R., K. Slark, S. J. Bertics, M. L. Luck, and J. A. Barmore. 1996. Soybeans versus animal sources of rumen-undegradable protein and fat for early lactation dairy cows. J. Dairy Sci. 79:1809-1816.

Ipharraguerre, I. R., and J. H. Clark. 2005. Impacts of the source and amount of crude protein on the intestinal supply of nitrogen fractions and performance of dairy cows. J. Dairy Sci. 88(E Suppl.):E22-E37.

Kerry, C. M., H. E. Amos, and M. A. Froetschel. 1993. Effects of supplemental protein source on intraruminal fermentation, protein degradability, and amino acid absorption. J. Dairy Sci. 76:514-524.

Knapp, D. M., R. R. Grummer, and M. R. Dentine. 1991. The response of lactating dairy cows to increasing levels of whole roasted soybeans. J. Dairy Sci. 74:2563-2572.

Leonardi, C., M. Stevenson, and L. E. Armentano. 2003. Effect of two levels of crude protein and methionine supplementation on performance of dairy cows. J. Dairy Sci. 86:4033-4042.

Lin, C., and L. Kung. 1999. Heat Treated Soybeans and Soybean Meal in Ruminant Nutrition. Tech. Bull. Am. Soybean Assoc. and United Soybean Board, St. Louis, MO.

Lykos, T., and G. A. Varga. 1995. Effects of processing method on degradation characteristics of protein and carbohydrate sources in situ. J. Dairy Sci. 78:1789-1801.
Mansfield, H. R., and M. D. Stern. 1994. Effects of soybean hulls and lignosulfonate-treated soybean meal, on ruminal fermentation in lactating dairy cows. J. Dairy Sci. 77:1070-1083.

Marsh, W. H., B. Fingerhut, and H. Miller. 1965. Automated and manual direct methods for the determination of blood urea. Clin. Chem. 11:624-627.

Nocek, J. E. 1988. In situ and other methods to estimate ruminal protein and energy digestibility: A review. J. Dairy Sci. 71:2051-2069.

NRC. 2001. Nutrient Requirements of Dairy Cattle. 7th ed. Natl. Acad. Press, Washington, DC.

Olmos Colmenero, J. J., and G. A. Broderick. 2006. Effect of dietary crude protein concentration on milk production and nitrogen utilization in lactating dairy cows. J. Dairy Sci. 89:1704-1712.

O’Mara, F. P., J. J. Murphy, and M. Rath. 1997. The amino acid composition of protein feedstuffs before and after ruminal incubation and after subsequent passage through the intestines for dairy cows. J. Anim. Sci. 75:1941-1949.

Pires, A. V., M. L. Eastridge, and J. L. Firkins. 1996. Roasted soybeans, blood meal, and tallow as sources of fat and ruminally undegradable protein in the diets of lactating cows. J. Dairy Sci. 79:1603-1610.

Polan, C. E., G. Cozzi, P. Berzaghi, and I. Andrighetto. 1997. A blend of animal and cereal protein or fish meal as partial replacement for soybean meal in the diets of lactating Holstein cows. J. Dairy Sci. 80:160-166.

Santos, F. A. P., J. E. P. Santos, C. B. Theurer, and J. T. Huber. 1998. Effects of rumen-undegradable protein on dairy cow performance: A 12-year literature review. J. Dairy Sci. 81:3182-3213.

Tamminga, S. 1979. Protein degradation in the forestomachs of ruminants. J. Anim. Sci. 49:1615-1630.

Vanzant, E. S., R. C. Cochran, and E. C. Titgemeyer. 1998. Standardization of in situ techniques for ruminant feedstuff evaluation. J. Anim. Sci. 76:2717-2729.

Voss, V. L., D. Stehr, L. D. Satter, and G. A. Broderick. 1988. Feeding lactating dairy cows proteins resistant to ruminal degradation. J. Dairy Sci. 71:2428-2439. 